\title{
DIPTEROCARPACEAE INVENTORY AT KETAMBE RESEARCH STATION, GUNUNG LEUSER NATIONAL PARK
}

\author{
Essy Harnelly*, Iqbar, Fauziah, Agus Sara, Nir Fathiya, and Rizky Amelia \\ Biology Department, Mathemathics and Natural Science Syiah Kuala University, Aceh \\ *Corresponding author: eharnelly@gmail.com
}

\begin{abstract}
This research was about Dipterocarpaceae inventory at Ketambe Research Station, Gunung Leuser National Park. The research was done on July 2015. Determination of sampling plot was using purposive sampling. The parameter observed was species as well as number of species. The result showed that there were 5 species of Dipterocarpaceae found in the sampling plot. All the species found were belongs to tribe of Shoreae namely; Shorea johorensis, Shorea parvifolia, Hopea dryobalanoides, Shorea lepidota, and Parashorea lucida.
\end{abstract}

Key words: Dipterocarpaceae, inventory, Gunung Leuser National Park

\section{INTRODUCTION}

Dipterocarpaceae is one of the big and important families of the timber trees. The name of the family, Dipterocarpaceae, is derived from one of its important genera Dipterocarpus and has 17 genera with more than 500 species (Maury-Lechon and Curtet 1998) out of which, 10 genera and 99 species are exclusively found in South Asia (Maguire and Ashton 1977). This family consists of three subfamilies: (1) Dipterocarpoideae in the Asian tropics and Seychelles, (2) Pakaraimoideae in Guyana and Venezuela of South America and (3) Monotoideae in African tropics, Madagascar and southeast Colombia of South America (Maury-Lechon and Curtet 1998; Ashton 1982; Ashton 2004). In Asian tropic, the sub family Dipterocarpoideae mostly found in Borneo, Malaysian Peninsula and Sumatra.

Gunung Leuser National Park is known as one of the world heritage for the rain forest which represents several ecosystems through tropical lowland forest ecosystem to mountain forest ecosystem. This national park is located at Aceh and North Sumatra Province. The Dipterocarpaceae family members are the most trees covered the forest spreading from low to the highest area. Ketambe research station, is one of the research station in the Gunung Leuser National Park, which has high and unique biodiversity. This research station lies on the South-East of the Leuser Mountain (Fig.1). Dipterocarpaceae is one of the family which dominated in that National forest followed by Meliaceae and Myrtaceae (Djojosudharmo et al. 2007).

\section{RESEARCH OBJECTIVE}

The aim of this research was to inventorying number of Dipterocarpaceae species as well as the number individual of each species which found in Ketambe research station, Gunung Leuser National Park.

\section{METHODS}

This research was done during July 2015 in the Ketambe research station, Aceh South-East District. The method applied was belt transect, on the purposive area, about 1 ha. The observation plot was measured $5 \mathrm{~m} \times 50$ $\mathrm{m}$ along the transect line. The total numbers of observation plots are 25 plots. The data was collected by observing the availability of Dipterocarpaceae species on the observation plot. The observation covered species and individual number of species. The location of the research area is showed from the map below (Fig. 1)

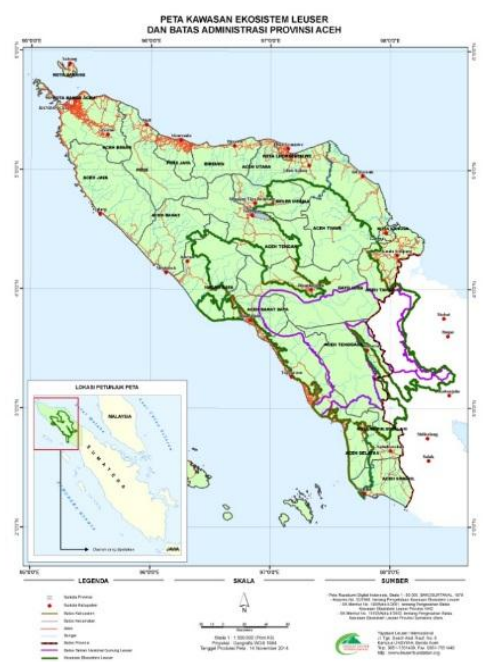

Fig 1. Map of the Leuser ecosystem area and administration border of Aceh

\section{RESULTS AND DISCUSSION}

Based on the early observation, we found there are five species of Dipterocarpaceae, belong to sub family 
Dipterocarpoideae, in Ketambe Research Station Gunung Leuser National Park (Table 1).

Table 1. List of Dipterocarpaceae found in Ketambe research station Gunung Leuser National Park

\begin{tabular}{llc}
\hline No & Species & Number of species \\
\hline 1 & Shorea parvifolia & 16 \\
2 & Shorea lepidota & 1 \\
3 & Shorea johorensis & 10 \\
4 & Hopea dryobalanoides & 1 \\
5 & Parashorea lucida & 110 \\
\hline
\end{tabular}

The Dipterocarpaceae members found in the research area were belongs to Dipterocarpoideae sub family, especially from Shoreae tribe members, namely; Shorea, Hopea and Parashorea. In this study, we observed that Parashorea lucida is the most dominant Dipterocarp in that forest (Fig. 2).

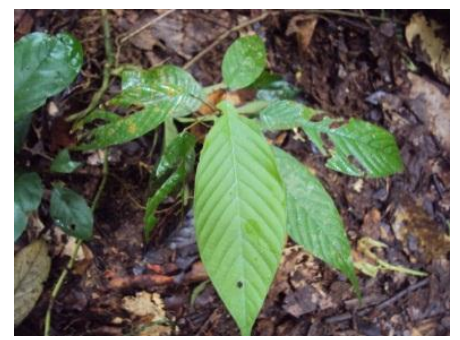

(a)

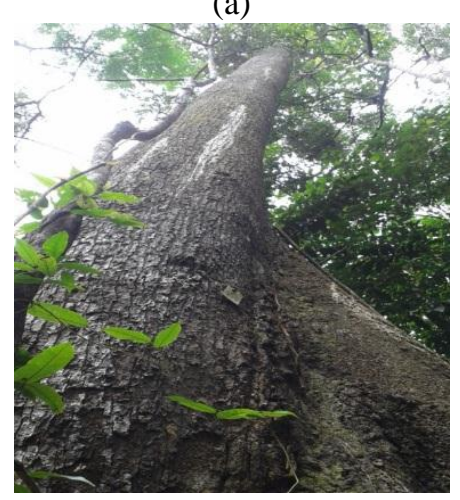

(b)

Fig. 2. Seedling of Parashorea lucida (a), adult tree of Parashorea lucida (b)

Parashorea lucida, known as meranti gerutu, is belongs to white meranti group. Even though this species has the good timber, however the abandon of Parashorea lucida, in Ketambe research station was indicated that the logger was not interested with this species, probably because of the wood is not easy to cut and need special tool to saw the tree compared to light red meranti group such as Shorea leprosula (Fig. 3a), Shorea johorensis (Fig. 3b), and Shorea lepidota.

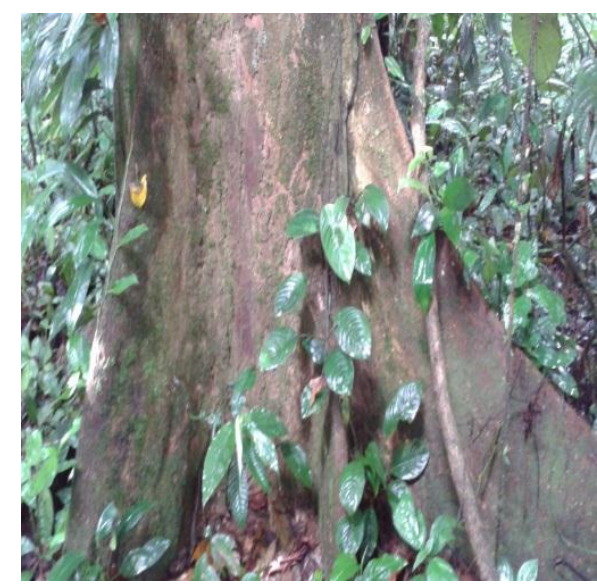

(a)

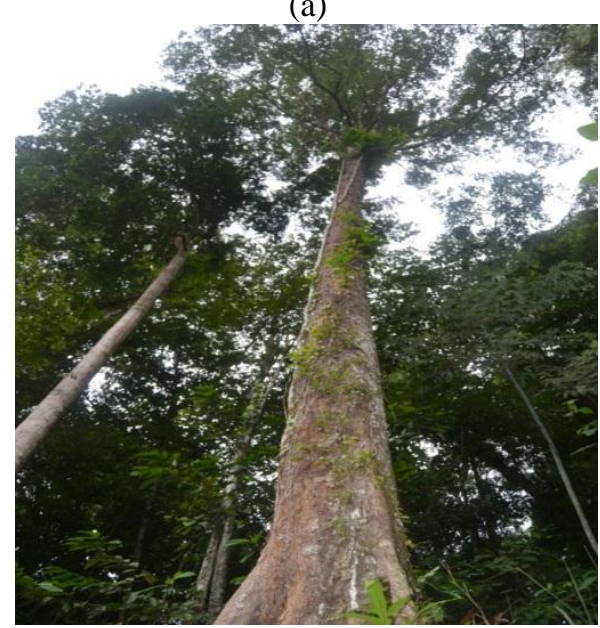

(b)

Fig. 3. Buttress tree: (a) Shorea leprosula, (b) Shorea johorensis tree

\section{CONCLUSION}

- The Dipterocarpaceae family in Ketambe Research Station Gunung Leuser National Park was dominated with Dipterocarpoideae sub family, especially Shoreae Tribe

- There were 5 species were found, namely Shorea parvifolia, Shorea lepidota, Shorea johorensis, Hopea dryobalanoides, and Parashorea lucida

- The most dominant species found in the research area was Parashorea lucida.

\section{ACKNOWLEDGMENT}

This project was funded by Indonesia Higher Education Ministry (DIKTI) through Fundamental scheme. Special thanks to our students, Rizky Amelya, S.Si, Nir Fathiya,S.Pd Samsul Muarif, S.Si, and Agus Sara who showed their dedicated in this project. 


\section{REFERENCE}

Ashton PS. 1982. Dipterocarpaceae. Flora Malesiana, Series I, 92: p237-552.

Ashton PS. 2004. Dipterocarpaceae. In Tree Flora of Sabah and Sarawak, Volume 5. Soepadmo, E., Saw, L. G. and Chung, R. C. K. eds. Government of Malaysia, Kuala Lumpur, Malaysia.

Djojosudharmo S, Atmoko USS, Azwar, Istiadi Y. 2007, Ketambe, Potensi Ekologi, Keanekaragaman Hayati, dan Sosial Masyarakat. Balai Besar TNGL, Medan
Maguire BPC, Ashton PS. 1977. Pakaramoideae, Dipterocarpaceae of the western hemisphere II. Systematic, geographic, and phyletic considerations. Taxon 26: 359-368.

Maury-Lechon G, Curtet L. 1998. Biogeography and Evolutionary Systematics of Dipterocarpaceae. In A Review of Dipterocarps: Taxonomy, ecology and silviculture. Appanah, S. and Turnbull, J. M. eds. Center for International Forestry Research, Bogor, Indonesia. 